\title{
Modelling post-absorptive protein and amino acid metabolism in the ruminant
}

\author{
BY MARK D. HANIGAN ${ }^{1}$, JAN DIJKSTRA ${ }^{2}$, WALTER J. J. GERRITS ${ }^{2}$ \\ AND JAMES FRANCE ${ }^{3}$ \\ 'Dairy Research Group, Purina Mills, Inc., 1401 South Hanley, St Louis, MO 63144, USA \\ ${ }^{2}$ Wageningen Institute of Animal Sciences (WIAS), Department of Animal Nutrition, Wageningen \\ Agricultural University, Marijkeweg 40,6709 PG Wageningen, The Netherlands \\ ${ }^{3}$ Institute of Grassland and Environmental Research, North Wyke Research Station, Okehampton, \\ Devon EX20 2SB
}

A goal of animal scientists has been to generate information capable of improving the productivity of farm animals. Historically, improvements in productivity have been achieved by enhancements in performance, i.e. increased rates of growth, lactation, etc. However, maximum performance may not always equate to maximum profit, particularly if one considers environmental costs associated with the animal enterprise (Tamminga, 1992). In addition, as generally each of the ingredients that can be fed has a different nutritive value and financial cost, various combinations of ingredients will yield different levels of performance and costs of production for the producer. In order to give due consideration to all these factors, mathematical equations adequate to describe the relationships between inputs and outputs must be formulated. Failure to formulate such relationships prevents one from truly maximizing profitability except in a serendipitous manner.

Mathematical systems describing the energetics of most ruminant farm animals have been formulated and parametrized (Jarrige, 1978; Van Es, 1978; Agricultural Research Council, 1980; National Research Council, 1989; Agricultural and Food Research Council, 1990). These systems have been refined over time and have served the industry well. However, the ruminant protein evaluation systems (Vérité et al. 1987; National Research Council, 1989; Agricultural and Food Research Council, 1992; Tamminga et al. 1994) have been less fruitful (Beever \& Cottrill, 1994). One common feature of these various systems is that they are based largely on empirical relationships derived from whole-animal observations. A major advantage to this approach is that the resulting model will usually be fairly simple and, thereby, easily deployed by the industry. However, if the problem of study is fairly complicated, as the description of protein requirements of animals appears to be, such an approach becomes cumbersome due to the inability to directly utilize data such as trans-organ fluxes or enzyme expression levels to describe and parametrize the model.

An alternative approach is to construct sub-models describing organ or cellular function and to aggregate and consolidate these sub-models into a system describing the whole animal. This approach lends itself to direct parametrization from organ, cellular, and subcellular data. It also allows the compartmentalization of the problem, which can be useful when dealing with very complicated systems.

In theory, one would identify these two approaches as discrete. However, in practice they represent the two ends of a continuous spectrum. Examples of empirical, mixed, and sub-model approaches for ruminant protein systems include the Cornell net carbohydrate and protein system (CNCPS; Fox et al. 1992; Russell et al. 1992; Sniffen et al. 1992; O'Connor et al. 1993), the models of Baldwin et al. (1987) and Gerrits et al. (1996); and the model of Gill et al. (1989) respectively. Although the objectives of these various 
models were completely different, each of the models contains components that can and should be drawn upon in the process of building application models for use by the animal industry. The objective of the present paper is to review some different approaches of modelling protein metabolism. The review will be restricted to post-absorptive protein metabolism in ruminants. The following are selected examples of the various models and some key concepts related to protein metabolism.

\section{THE CORNELL NET CARBOHYDRATE AND PROTEIN SYSTEM}

The CNCPS model (Fox et al. 1992; Russell et al. 1992; Sniffen et al. 1992; O'Connor et al. 1993) was constructed for use on-farm by animal nutritionists, to predict nutrient requirements and animal performance. As such, the model is aggregated at the wholeanimal level and considers animal energetics and protein metabolism. The model is unique in that it is the only whole-animal model to include descriptions of both energetics and amino acid (AA) metabolism in ruminating animals.

The critical elements of post-absorptive AA metabolism of the CNCPS are presented in Fig. 1. The overall post-absorptive system was adopted from National Research Council (1985) with AA descriptions added by O'Connor et al. (1993). The CNCPS model attempts to segregate post-absorptive protein and AA metabolism into discrete functions. However, these apparently discrete functions are actually empirical relationships based largely on whole-animal observations as presented by National Research Council (1985). AA utilization in the post-absorptive portion of the model was grouped into four categories: (a) maintenance, (b) tissue accretion, (c) lactation, (d) gestation.

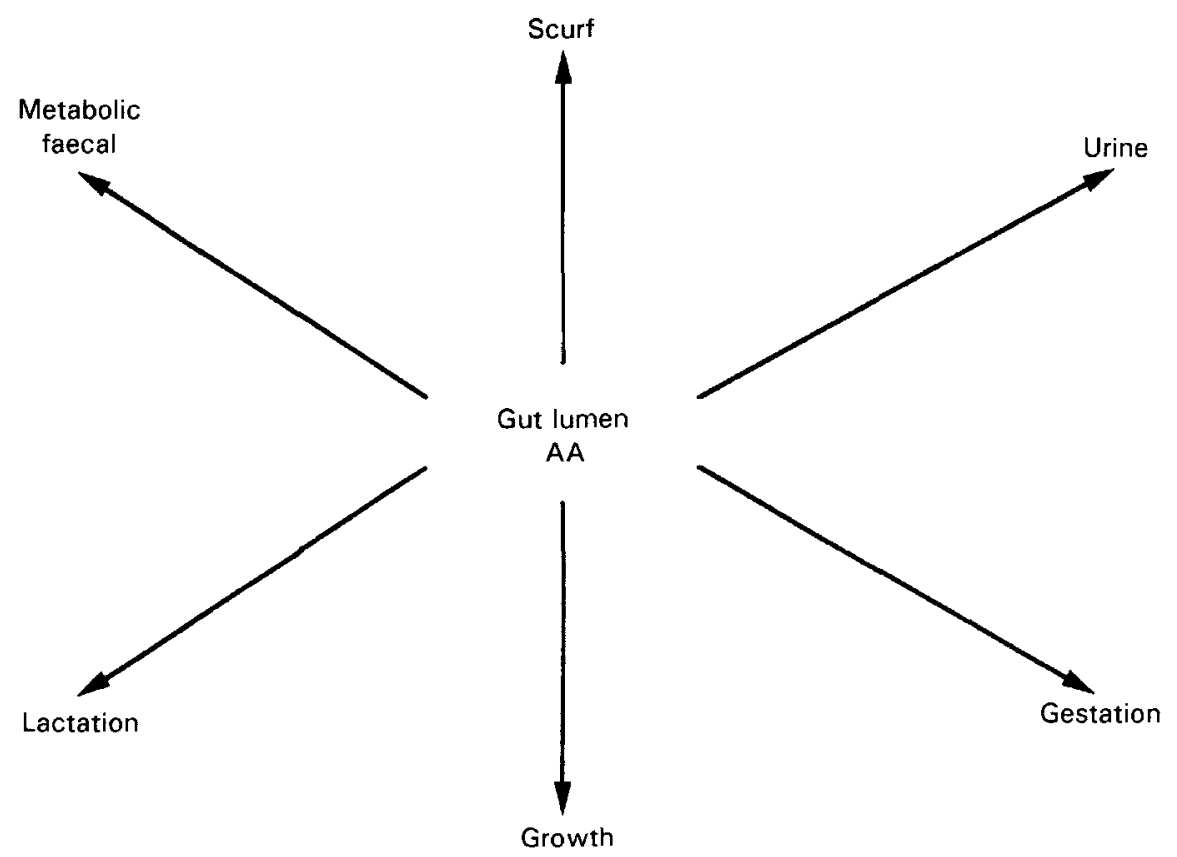

Fig. 1. Diagrammatic representation of the post-absorptive amino acid (AA) and protein metabolism in the Cornell net carbohydrate and protein system (Fox et at. 1992; Russell et al. 1992; Sniffen et al. 1992; O'Connor et al. 1993). 
AA requirements for maintenance were based on the protein requirements by use for scurf, loss in urine, and metabolic faecal losses, as presented by National Research Council (1985). These are a function of the body weight (BW), indigestible DM intake, the assumed AA composition of maintenance protein, and the efficiencies of utilization of AA for maintenance (EAAM). EAAM was set to 0.66 for branched-chain amino acids (BCAA) and 0.85 for the remaining essential amino acids (EAA). Therefore, the efficiency of utilization of the BCAA for maintenance is equivalent to previous values $(0 \cdot 67)$ used for some metabolizable protein systems (National Research Council, 1985; Tamminga et al. 1994), while that of the remaining EAA is higher; but both were lower than the value applied in the UK system (1.0; Agricultural and Food Research Council, 1992).

Requirements for growth were represented as a function of the empty-body gain (EBG; calculated from National Research Council, 1985), the protein content of EBG, the EAA composition of tissue protein, and the efficiency of use of EAA for growth processes (EAAG). EAAG was assumed to vary with stage of growth and calculated as a function of the relative BW (RBW). The RBW is calculated by adjusting the actual BW to the BW of a National Research Council (1984) medium-framed steer of equal body composition (Fox $e t$ al. 1992). For steers, assuming a frame score of 5 at $240 \mathrm{~kg} \mathrm{BW}$, EAAG values calculated in this way $(0.59)$ compare favourably with observed values $(0.58$ for hindlimb fluxes; Boisclair et al. 1993). However, if adjustment factors for heifers are applied to mature cows, EAAG would become negative in some situations and calculated AA catabolization is not in line with calculated urinary protein losses.

EAA requirements for lactation were a function of milk true-protein yield (calculated from Fox et al. 1992), the EAA content of milk true protein (adopted from Waghorn \& Baldwin, 1984), and the efficiencies of use of individual EAA for lactation (EAAL). EAAL ranges from a low of 0.42 (arginine) to 1.0 (phenylalanine), adopted from Oldham (1980) and Evans \& Patterson (1985). However, EAA uptake and utilization by the mammary gland has been observed to be variable (Metcalf et al. 1994, 1996). A similar approach was taken for predicting the EAA requirements for conceptus and gravid uterine growth in the pregnant animal with efficiencies of conversion ranging from 0.66 for BCAA and arginine to 0.85 for the remaining EAA.

Summation of these processes for each AA then gives the total use of that AA and thereby the requirement. Whole-animal in vivo measurements including $\mathrm{BW}$ and wholebody protein synthesis can be employed to parametrize and evaluate the model. However, maintenance and growth descriptions contain components of multiple tissue beds and, therefore, cannot be derived from arterio-venous concentration $(A-V)$ difference data, except through extensive use of assumptions and conversion of data. Although lactation and gestation are defined as discrete processes and, therefore, can be fitted to data (typically blood flow and AA concentrations), the form of the equations does not allow for direct application. Also, the design of the model and the form of the equations do not allow for explicit representation of AA requirements for non-protein synthesis purposes, notably gluconeogenesis, or for substrate interactions.

\section{BALDWIN ET AL. (1987) MODEL}

The model of Baldwin et al. (1987) is also aggregated at the whole-animal level and considers animal energetics and protein metabolism. The model was developed to evaluate current concepts and data for probable adequacy as explanations of variations in nutrient partitioning in lactating cows, and constructed utilizing dynamic relationships allowing integration over time. Three tissue beds were explicitly considered: lean body, adipose and 
viscera. Consideration of functions specific to mammary gland and liver were also included in the model. A schematic representation of the protein metabolism components is shown in Fig. 2. Carbohydrate and lipid classes of metabolites were also considered in this model, permitting the direct integration of protein and energy metabolism.

AA were treated as a single pool. Utilization of AA by lean body and viscera for growth, by mammary gland for milk protein synthesis, and by liver for glucose and for energy production were a function of systemic AA concentration:

$$
\begin{gathered}
U_{A A, A A P b}=\frac{V_{A A P b}}{1+\frac{K_{A A P b}\left(\frac{C_{G l_{o}}}{C_{G l}}\right)^{2 \cdot 0}}{C_{A A}}, \quad U_{A A, A A P v}}=\frac{V_{A A P v}}{1+\frac{K_{A A P v}\left(\frac{C_{G l_{o}}}{C_{G l}}\right)^{2 \cdot 0}}{C_{A A}}}, \\
U_{A A, A A P m}=\frac{V_{A A P m}}{1+\frac{K_{A A P m}}{C_{A A}}}, \quad U_{A A, A A G l}=\frac{V_{A A G l}}{1+\frac{K_{A A g l}\left(\frac{C_{G l}}{C_{G l o}}\right)^{2 \cdot 0}}{C_{A A}}},
\end{gathered}
$$

where $U_{A A, A A P b}, U_{A A, A A P v}, U_{A A, A A P m}$, and $U_{A A, A A G l}$ are the utilization of AA for protein synthesis in the lean body, protein synthesis in the viscera, milk protein synthesis, and conversion to glucose and other oxidative intermediates respectively. $K_{A A P b}, K_{A A P V}, K_{A A P m}$, and $K_{A A G t}$ are the apparent affinity constants for the respective fluxes and $V_{A A P b}, V_{A A P V}$, $V_{A A P m}$, and $V_{A A G l}$ are the maximal velocities for each of the respective processes. $C_{A A}$ is

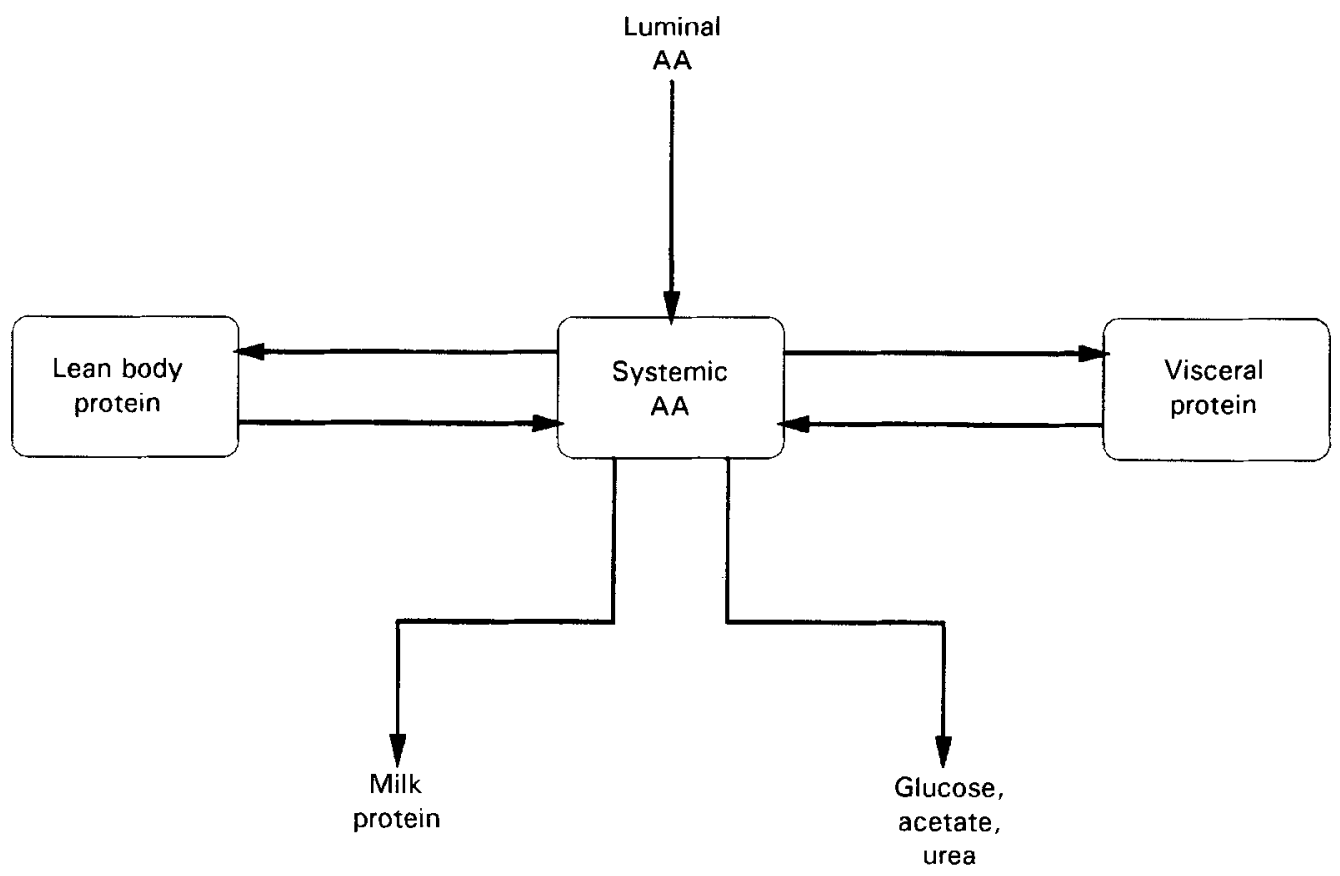

Fig. 2. Diagrammatic representation of the post-absorptive amino acid (AA) and protein metabolism in the Baldwin et al. (1987) model. 
AA concentration. $C_{G l}$ and $C_{G l_{o}}$ are glucose and reference glucose concentrations respectively and are used as an indicator of hormonal status, in particular, insulin and glucagon. Therefore, an increase in glucose concentrations relative to the reference concentrations results in increases in rates of AA use for protein synthesis in viscera and body and a decline in AA catabolism with no change in rates of milk protein synthesis. The relative magnitude of the changes are a function of the rate-constants in the individual flux equations and the exponent used to scale the glucose ratio. As each of the parameters must be defined, efforts to derive these parameters from data are needed. It is not clear whether current data are adequate to derive these parameters for each of the various tissues represented by the model equations.

Protein degradation in the body and visceral pools ( $P_{A A, P b A A}$ and $P_{A A, P V A A}$ respectively) were assumed to be linearly related to protein mass and affected by hormonal status using a similar scheme to that for protein synthesis.

$$
P_{A A, P b A A}=k_{P b A A}\left(\frac{C_{G l_{o}}}{C_{G l}}\right)^{2.0} P b, \quad P_{A A, P v A A}=k_{P v A A}\left(\frac{C_{G l_{O}}}{C_{G l}}\right)^{2.0} P \nu
$$

However, the hormonal regulation is reciprocal in that increases in glucose concentrations cause reductions in protein degradation in these two tissues. The addition of a defined AA catabolic flux is a valuable addition compared with the efforts of O'Connor et al. (1993). Lean body and visceral protein catabolic fluxes were assumed to be homogeneous, which is probably not the case given the variety of tissues that take part in these processes. However, the errors associated with this aggregation have not been quantified.

In general, the dynamic approach in this model offers some advantages to the functionbased CNCPS approach: (1) individual tissues are explicitly defined. Although they are highly aggregated, this allows more extensive use of tissue level data to define parameters; (2) the model incorporates the concept of tissue competition for a finite supply of AA; (3) the apparent affinity of tissues for AA can be altered independent of other tissues to more accurately represent observations; (4) the predicted efficiency of utilization of AA is not fixed, but can vary widely, dependent on the dietary conditions, in line with experimental observations. However, the aggregated nature of AA descriptions would not be adequate to simulate reduction in protein synthesis rates brought about by limitations in single EAA such as methionine or phenylalanine.

\section{GERRITS ET AL. (1996) MODEL}

Like the model of Baldwin et al. (1987), the model of Gerrits et al. (1996) is aggregated at the whole-animal level. In addition it includes a description of EAA and non-essential AA (NEAA) metabolism at the tissue level, thus offering advantages relative to the CNCPS model when utilizing tissue level data. This research model was developed to obtain insight into the partitioning of nutrients from ingestion through intermediary metabolism to protein, fat and ash accretion in growing preruminant calves. A schematic representation of the protein metabolism components is shown in Fig. 3.

The body storage pools comprise chemical fat, ash, and four protein pools. Body protein was split up into protein pools from several anatomical tissues: muscle, viscera, bone, and hide. Synthesis of protein was related to energy and AA supply and depends on the concentrations of acetyl-CoA equivalents (AcCoA) and of AA, with equations to describe the transactions similar to those presented for the Baldwin et al. (1987) model. Turnover of each protein pool was represented with fixed fractional degradation rates (\%/ d), applied linearly to each tissue bed, of 2.0 muscle protein, 24.5 visceral protein, 4.0 hide 
protein, and $6 \cdot 1$ bone protein. Thus, unlike the Baldwin et al. (1987) model, fractional degradation rates did not vary according to nutritional status. Endogenous urinary $\mathrm{N}$ loss, net endogenous protein loss in faeces, and losses of scurf, were modelled as a drain on the AA metabolite pool, the visceral protein pool, and the hide protein pool respectively.

In this model, an improper balance of dietary AA will limit protein synthesis and increase AA catabolism. An AA profile was assigned to each of the body protein pools and to dietary protein, based on various literature references. Then, in a calculation routine performed every iteration, the individual AA supply (AA from diet and from degradation of each body protein pool) and demand (AA for protein synthesis and for inevitable oxidative losses of each AA) were compared. Inevitable losses of AA have been introduced (because potential re-utilization of degraded protein for protein synthesis is always less than $100 \%$; Simon, 1989) and were assumed to be $2 \%$ of the AA supplied from diet and from body protein degradation. If the supply of a NEAA is less than that required, the cost of synthesis of that NEAA is calculated, which requires AcCoA for the transformation. If the supply of one (or more) EAA is lower than demand, protein synthesis is calculated based on the supply of the most-limiting EAA, and it is assumed that all the AA supplied in excess are oxidized. In case no EAA is limiting, AA oxidation depends on the general AA concentration, and for simplicity is assumed to occur in the liver. The advantages mentioned for the Baldwin et al. (1987) model, related to distinct tissue beds and to efficiency of nutrient utilization which will vary according to supply of other nutrients, are valid as well for the Gerrits et al. (1996) model. The representation of various protein pools

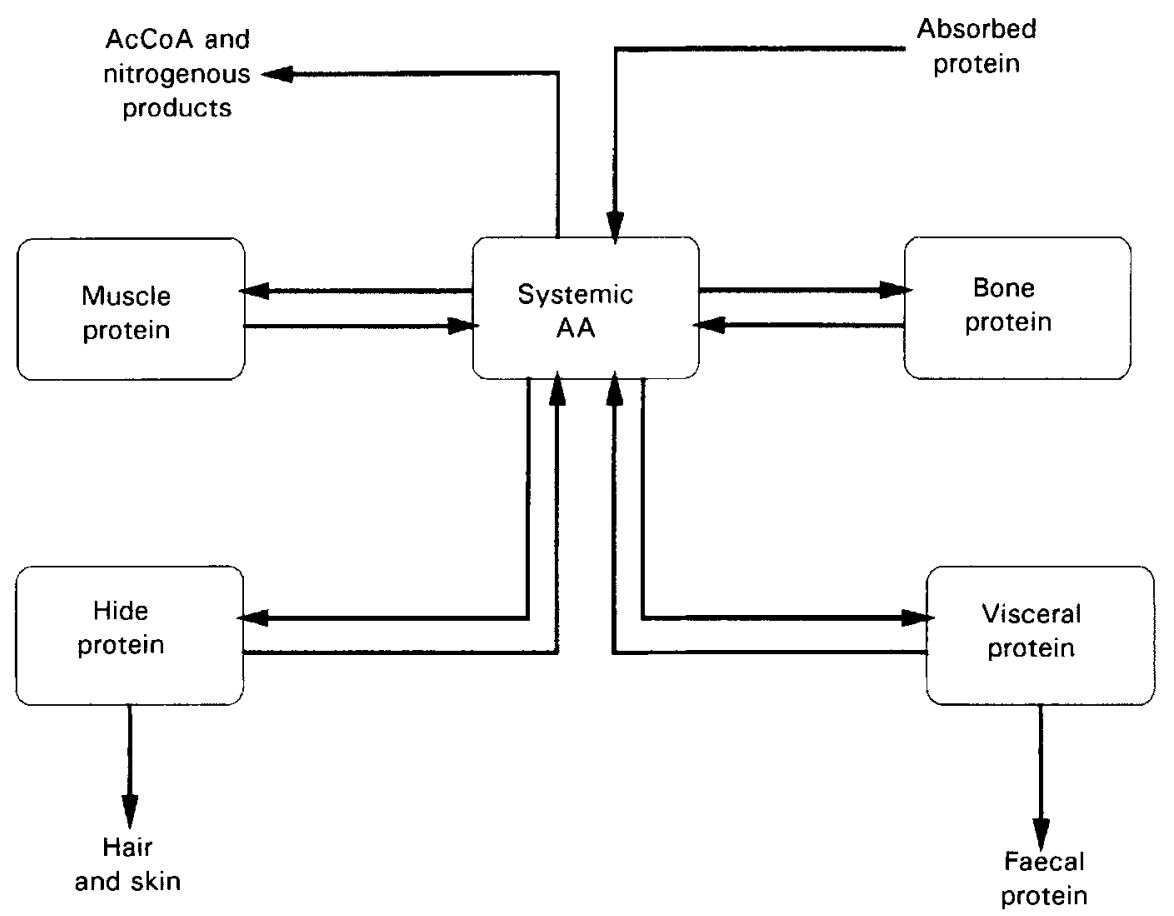

Fig. 3. Diagrammatic representation of the post-absorptive amino acid (AA) and protein metabolism in the Gerrits et al. (1996) model. AcCoA, acetyl-CoA. 
and their individual AA composition and specific degradation rates, provides a promising tool in practical feed evaluation, to indicate the occurrence of limiting AA and to optimize the dietary AA composition. For example, the simulated requirements of methionine + cystine $(13 \mathrm{~g} / \mathrm{d})$ and of lysine $(24 \mathrm{~g} / \mathrm{d})$ of a calf of $235 \mathrm{~kg} \mathrm{BW}$ with a $\mathrm{N}$ retention of $36 \mathrm{~g} / \mathrm{d}$, could explain the lack of response in $\mathrm{N}$ balance of calves fed on diets in which methionine + cystine varied from 13 to $21 \mathrm{~g} / \mathrm{d}$, and that of lysine from 27 to $45 \mathrm{~g} / \mathrm{d}$ (Tolman et al. 1991). Further improvements of this model can be made by applying fractional degradation rates of body protein pools which vary with protein synthesis rates (Jepson et al. 1988; Liu et al. 1995). Also, refinements would be beneficial, related to regulation of AA oxidation rates and the site of AA oxidation (Benevenga et al. 1993). In terms of fitting the model to A-V difference data in individual tissue beds, the aggregation of gastrointestinal tract (GIT) and liver results in similar problems to those for the CNCPS model (O'Connor et al. 1993) and for the Baldwin et al. (1987) model.

\section{GILL ET AL. (1989) MODEL}

Gill et al. (1989) adopted an approach that was based on the description of individual tissues as opposed to the function-based approach adopted by National Research Council $(1985,1989)$ and O'Connor et al. (1993), and the more aggregated approach of Baldwin et al. (1987) and Gerrits et al. (1996). The model was designed to examine the effects of AA supply on whole-animal protein metabolism. Ten tissue beds, adipose, central nervous system (CNS), GIT, heart, kidney, liver, muscle, pancreatic and salivary glands (PSG), reticulo-endothelial system (RES), and skin, were defined explicitly. A schematic representation of this dynamic model is shown in Fig. 4. The model has a common blood AA pool $\left(Q_{B l A A}\right)$ which is a function of inputs and outputs, the rate of change described by:

$$
d Q_{B l A A} / d t=\sum P_{B L A A i}-\sum U_{B L A A i}
$$

where $d Q_{B L A A} / d t$ represents the change in $Q_{B l A A}$ with respect to time. $P_{B L A A i}$ and $U_{B l A A i}$ represent the release and the removal of AA by the individual tissues and are of the form:

$$
\begin{aligned}
P_{B L A A i} & =K c_{i} Q a_{i}, \\
U_{B I A A i} & =K b_{i} C_{B I A A} V_{B l},
\end{aligned}
$$

where $K c_{i}, Q a_{i}$, and $K b_{i}$ represent the rate-constant for release of AA by, the amount of free $\mathrm{AA}$ in, and the rate-constant for removal of AA by the $i$ th tissue respectively, and $C_{B I A A}$ and $V_{B l}$ represent the concentration of blood $\mathrm{AA}$ and the volume of blood. Tissue AA metabolism rate was given as:

$$
\begin{gathered}
d Q a_{i} / d t=P_{i}+U_{B L A A i}-U_{i}-P_{B I A A i} \\
d Q p_{i} / d t=U_{i}-P_{i} \\
U_{i}=V u_{i} Q p_{i} /\left(1+K u_{i} / C_{A A i}\right) \\
P_{i}=V p_{i} Q p_{i} /\left(1+C_{A A} / K p_{i}\right)
\end{gathered}
$$

where $d Q a_{i} / d t$ and $d Q p_{i} / d t$ represent the change in amount of free AA and of proteinbound AA $\left(Q p_{i}\right)$ with respect to time in the $i$ th tissue. $U_{i}, P_{\mathrm{i}}, V u_{i}, V p_{i}, K u_{i}$, and $K p_{i}$ represent the utilization, production, maximal velocity for protein synthesis, maximal velocity for protein catabolism, apparent affinity constant for AA, and apparent affinity constant for 


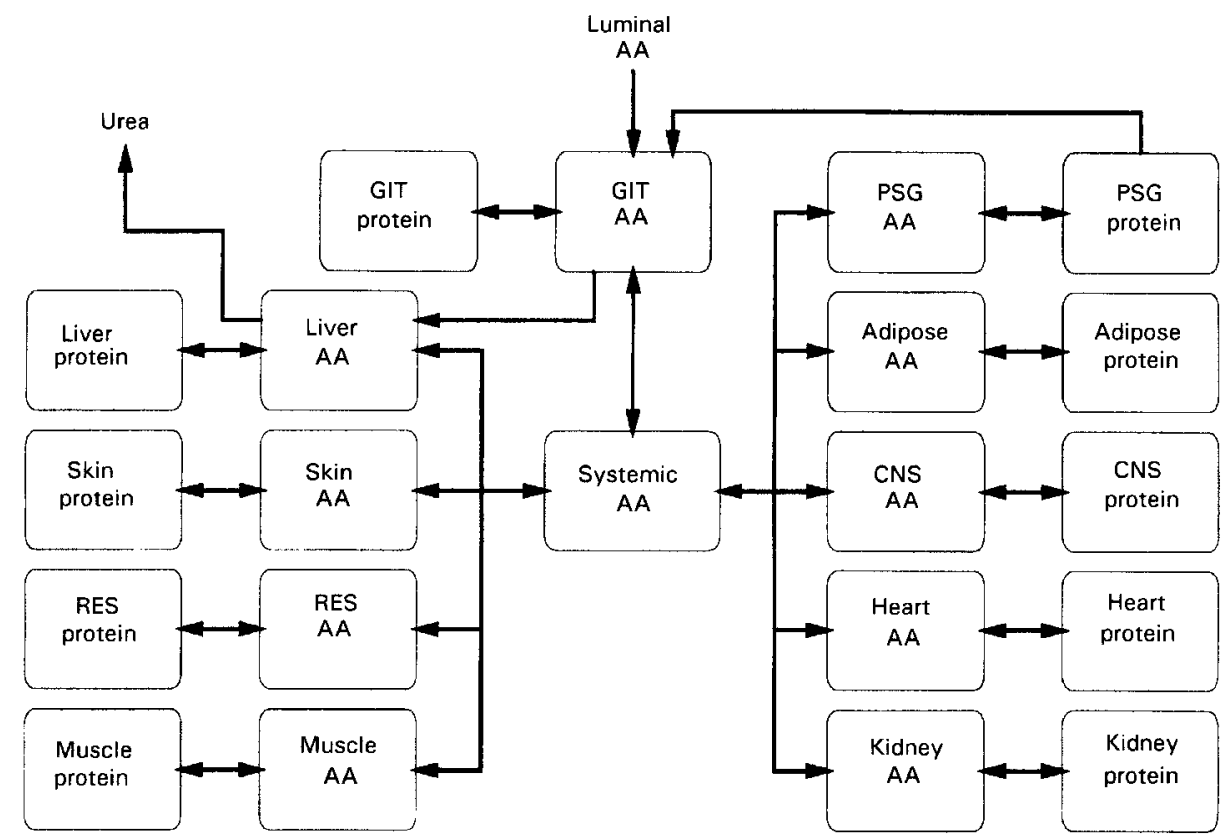

Fig. 4. Diagrammatic representation of the post-absorptive amino acid (AA) and protein metabolism in the Gill et al. (1989) model. GIT, gastrointestinal tract; CNS, central nervous system; RES, reticulo-endothelial system; PSG, pancreatic and salivary glands.

protein for the $i$ th tissue. The only exceptions to this generalized model are the additional input into the GIT free-AA pool arising from the absorption of dietary and endogenous AA from the gut lumen and a fractional transfer of AA from the gut AA pool directly to the liver AA pool without entry into the common AA pool.

Like the Gerrits et al. (1996) model, AA catabolism is treated as a homogenous process, i.e. catabolism only occurs in the liver. However, with individual representations of tissues, one could apply catabolic rates to each individual tissue, as quantified recently (Lobley et al. 1995, 1996), and sum those processes at the level of the liver to quantify total urea output. Gill et al. (1989) have chosen to represent protein catabolism as a function of tissue protein mass and tissue AA availability. Their representation will result in a decline in protein degradation as protein synthesis rates increase, rather than the expected increase in protein catabolism (Jepson et al. 1988; Liu et al. 1995).

Entry of absorbed AA into the GIT free-AA pool will result in an increase in gut mass (or AA catabolism if it were considered) if supply increases. This concept is not supported by recent data which indicate that AA seem to be utilized primarily from systemic sources as opposed to luminal supplies (MacRae et al. 1997b).

This model is similar in nature to that of Baldwin et al. (1987), however it is less aggregated, thereby requiring fewer assumptions when fitted to most in vivo data at the organ or tissue level. Limitations of this model, when attempting to use it as a simulation model outside its original objective, include: (1) AA are defined as a common pool and, therefore, the model cannot be used to examine the effects of one or more limiting AA; (2) a high level of complexity is associated with the large number of tissues that are represented; (3) some manipulation of data and assumptions must be made to utilize some 
types of in vivo data, i.e. A-V difference data cannot be used directly to derive parameters; (4) mammary metabolism is not considered; (5) metabolites of a non-nitrogenous character are not considered, preventing integration of energy and protein metabolism. However, if limitations 1 and 4 were addressed, this model could possibly be parametrized using existing data.

\section{INTEGRATED TISSUE AND TRACER MODELS}

Waghorn \& Baldwin (1984), Freetly et al. (1993) and Hanigan \& Baldwin (1994) have constructed models of intermediary metabolism in the liver or the mammary gland, with the objective of simulating whole-organ or tissue metabolism. These efforts included a minimal representation of AA metabolism, i.e. discrete representation of a few selected AA with the remainder being represented by an aggregated pool. Analogous to the body protein synthesis calculation in the model of Gerrits et al. (1996), predictions of milk protein output by mammary gland in the Hanigan \& Baldwin (1994) model are a function of the first-limiting AA among those listed previously. However, unlike the whole-animal model of Gerrits et al. (1996), it is assumed that no oxidation of the first-limiting AA occurs. The remaining AA are incorporated into milk protein at a rate determined by the first-limiting AA and their molar proportions in milk protein. Excess AA from this latter group are then catabolized through the appropriate pathways. A similar approach is used in the wholeanimal model of O'Connor et al. (1993), although the pathways of catabolism are not defined. It is not currently known whether such an approach is adequate. Given that protein synthesis can be regulated at both the transcriptional and the translational levels, there are no assurances that this approach will prove adequate.

Estimates of protein turnover kinetics in tissues and organs have been obtained by using tracer methods in conjunction with simple compartmental models. The basic model to interpret tracer data in the steady-state is the precursor-product model detailed by Waterlow et al. (1978). Assuming a system of two pools, i.e. the precursor AA (QAA) and the tissue protein pool $\left(\mathrm{Q}_{\mathrm{P}}\right)$, conservation of mass principles in steady-state conditions and using some assumptions yields the simple expression:

$$
F_{P A A}=I / s_{A A}-F_{O X A A},
$$

where $F_{P A A}$ and $F_{O X A A}$ represent protein synthesis and AA catabolism respectively, $I$ is the constant rate of infusion of label, and $s_{A A}$ is the specific activity of the precursor pool. This Waterlow et al. (1978) equation has been used to estimate the rate of whole-body protein synthesis in ruminants, taking plasma AA as the precursor pool. For example, Lobley et al. (1980) obtained protein synthesis estimates for cattle, following infusion of $\left[{ }^{3} \mathrm{H}\right]$ leucine and $\left[{ }^{3} \mathrm{H}\right]$ tyrosine. No correction was made for oxidation $\left(F_{O x A A}\right)$, and protein synthesis estimates based on tyrosine were approximately $60 \%$ higher than those based on leucine, suggesting the tyrosine estimates include a relatively large oxidation component. The need to measure oxidation rates can be circumvented by introducing some kinetic assumptions into the model and considering the product pool, which will yield the Garlick et al. (1973) equation. This equation has been widely applied to the calculation of protein synthesis rates for various tissues in cattle, and such estimates have been adopted in various whole-animal models (Baldwin et al. 1987; Gerrits et al. 1996). Further methods have been applied to overcome the problem of direct measurement of precursor specific activity, as reviewed by France et al. (1988).

Tracer methods and simple compartmental models can yield even more information if supplemented with A-V difference measurements. For example, France et al. (1995) 
developed such a model to resolve data generated using an in vivo $\mathrm{A}-\mathrm{V}$ difference preparation of the mammary gland coupled with infusions of $\left[{ }^{13} \mathrm{C}\right]$ leucine into the jugular vein of lactating dairy cattle (Bequette et al. 1996). Application of the model to experimental data indicated milk protein and tissue protein synthesis rates which ranged from 0.61 to 0.69 and 0.13 to $0.37 \mathrm{~mol} \mathrm{leucine/d} \mathrm{respectively.} \mathrm{AA} \mathrm{uptake} \mathrm{and} \mathrm{efflux}$ estimates could be used to generate estimates of AA removal in whole-animal models. These estimates of protein turnover in individual tissues are vital in whole-animal models, as they will affect the energy fluxes involved in these processes and possibly the AA requirements of the animal (Gerrits et al. 1996).

\section{FUTURE EFFORTS}

Whole-animal models currently available (Baldwin et al. 1987; O'Connor et al. 1993; Gerrits et al. 1996) deal with many of the tissues on an aggregated scale. This is a wholly appropriate choice in that as one moves closer to the level of field application, the complexity of the model must decrease. However, as noted previously, further refinement of these models requires additional knowledge at the tissue level. It can be difficult to make full use of the variety of data sets that have been and are currently being collected at that level when dealing with such an aggregated system. An alternative approach is to build integrated tissue-level models that can make direct use of these data. Such models can then be used, after they have been parametrized and tested, to help derive more aggregated relationships that can be incorporated into the whole-animal models. These tissue-level models of intermediary metabolism, including complete descriptions of AA metabolism, are largely absent. Also, in whole-animal models it is not necessary or desirable to represent every single tissue or organ in detail. The work of Gill et al. (1989) would suggest that based on relative rates of protein synthesis, the RES, PSG, adipose, CNS, heart, and kidney tissues could be aggregated into a single entity representing between 14 and $18 \%$ of the total body synthetic rates for a young non-lactating animal. This aggregation would greatly reduce the effort required to develop tissue models. As measurements of AA fluxes in these varied tissues may prove to be beyond our current technical means, parameter estimates for the other tissues must be defined with minimal errors in order to allow the estimates for this aggregated tissue bed to be derived by difference, i.e. estimates of uptake are calculated from total input and predicted rates of utilization by other tissues.

Key aspects in future efforts to construct models of post-absorptive protein metabolism include: first, the delivery of nutrients to organs and tissues by blood; second, improved descriptions of AA metabolism in all organs and tissues. AA are carried to the various tissues in blood. Calculating AA delivery based on flow and concentration then yields units of mass per time. It has been clearly demonstrated that AA removal by tissues is concentration dependent (Oxender \& Christensen, 1963). If the tissues are net utilizers of AA, then changes in blood flow will result in changes in AA concentrations in the extracellular space (Cant \& McBride, 1995; Hanigan et al. 1996) and, thereby, removal by the tissue. However, all models that currently consider AA removal from a blood pool (Waghorn \& Baldwin, 1984; Baldwin et al. 1987; Gill et al. 1989; Freetly et al. 1993; Hanigan \& Baldwin, 1994) have described AA delivery entirely as a function of arterial AA concentration. Such a description provides the proper units for application to tissue removal but ignores the potential effects of blood flow on AA delivery. Additionally, such an approach prevents direct utilization of $\mathrm{A}-\mathrm{V}$ difference data for parameter estimation. One could easily adapt current models to consider the effects of changes in blood flow to 
the various tissues by replacing the current tissue uptake equations with the simple algebraic expression presented by Hanigan et al. (1996). Although such an adaptation would add some complexity to the models, this additional complexity would be no greater than that required to describe blood flow to the various tissue beds. Such an addition would allow direct utilization of $\mathrm{A}-\mathrm{V}$ difference data and blood flow data and should provide a more accurate representation of the physiology.

Second, more complete descriptions of AA metabolism are required for all tissues. In particular, the complete lack of a model of GIT metabolism must be addressed in order to make progress at the animal level. Tagari \& Bergman (1978) observed extensive utilization of AA by the GIT. More recent observations by MacRae et al. $(1977 a, b)$ support the observations of Tagari \& Bergman (1978). However, the isotopic movement observed by MacRae et al. (1997a) indicates that the majority of AA that are catabolized are derived from systemic supplies. Therefore, attempts to model this tissue bed would need to accommodate inputs from arterial supply and luminal absorption and the apparent effects of systemic supply on AA catabolism.

Clearly more complete descriptions of liver and mammary models are required. It would seem that these efforts are now possible given the recent activity by experimenters in the area. Numerous data sets containing measurements of AA flux across these tissues are now becoming available (Cant et al. 1993; Hanigan \& Baldwin, 1994; Metcalf et al. 1994, 1996; Lobley et al. 1996), and some of these data sets are supplemented by isotopic flux measurements (Lobley et al. 1996). Efforts to model these data should yield valuable insight on the metabolism of all substrates by these tissues. Additionally, the mammary data should be extensive enough to thoroughly test the ability of the simple firstlimiting AA representation of milk protein synthesis. One limitation identified by Freetly $e t$ al. (1993) was the inadequate supply of lipid precursors to account for observed free fatty acid oxidation and triacylglycerol synthesis rates in the liver. While this may not have a bearing on AA supply, the potential interaction among $\mathrm{C}$ sources and oxidation of AA cannot be ignored. It does not appear that any of the more recent data sets are adequate to address this problem. Another major assumption made by Freetly et al. (1993) was related to the rate of utilization of AA for export protein synthesis. The recent data of Connell $e t$ al. (1997) can be utilized to help address this assumption.

A similar effort is required for muscle and skin. The aggregation of these two tissues is obvious from the point that most in vivo measurements of muscle metabolism are taken from the hindlimb which would include both muscle and skin. The data in this area are less extensive, but the recent data of Harris et al. (1992) and Boisclair et al. (1993) will be useful in the modelling effort. However, hindlimb metabolism would include bone protein metabolism as well, and the AA composition and turnover rates of muscle, skin and bone protein can be very different when compared with each other (Simon, 1989).

A more extensive data base will probably be required for parametrization and evaluation of models at tissue and whole-animal level models. In particular, the current method of operation wherein the modeller is responsible for sequestration of the data from a variety of sources and subsequent organization of the data greatly hampers the progress that can be made. A central repository for data would be very useful from a modelling standpoint in that it would reduce the effort to gather and format data. However, it would still be incumbent upon the modeller to ensure the correct interpretation and accuracy of the data before use.

In summary, a great deal of future effort is required to construct and parametrize tissue models. Although modelling at the tissue level should yield significant long-term results, such an endeavour will probably yield very little tangible improvement at the animal level 
in the short term. Of course, this presumed progress will only be realized if the tissue level work is extended to the whole-animal models.

\section{REFERENCES}

Agricultural and Food Research Council (1990). AFRC Technical Committee on Responses to Nutrients. Report no. 5. Nutritive requirements of ruminant animals: energy. Nutrition Abstracts and Reviews 60, 729-804.

Agricultural and Food Research Council (1992). AFRC Technical Committee on Responses to Nutrients. Report no. 9. Nutritive requirements of ruminant animals: protein. Nutrition Abstracts and Reviews 62, 787-835.

Agricultural Research Council (1980). The Nutrient Requirements of Ruminant Livestock. Farnham Royal: Commonwealth Agricultural Bureaux.

Baldwin, R. L., France, J. \& Gill, M. (1987). Metabolism of the lactating cow. I. Animal elements of a mechanistic model. Journal of Dairy Research 54, 77-105.

Beever, D. E. \& Cottrill, B. R. (1994). Protein systems for feeding ruminant livestock: a European assessment. Journal of Dairy Science 77, 2031-2043.

Benevenga, N. J., Gahl, M. \& Blemings, K. P. (1993). Role of protein synthesis in amino acid catabolism. Journal of Nutrition 123, 332-336.

Bequette, B. J., Metcalf, J. A., Wray-Cahen, D., Backwell, F. R. C., Sutton, J. D., Lomax, M. A., MacRae, J. C. \& Lobley, G. E. (1996). Leucine and protein metabolism in the lactating dairy cow mammary glandresponses to supplementary dietary crude protein intake. Journal of Dairy Research 63, 209-222.

Boisclair, Y. R., Bell, A. W., Dunshea, F. R., Harkins, M. \& Bauman, D. E. (1993). Evaluation of the arteriovenous difference technique to simultaneously estimate protein synthesis and degradation in the hindlimb of fed and chronically underfed steers. Journal of Nutrition 123, 1076-1088.

Cant, J. P., DePeters, E. J. \& Baldwin, R. L. (1993). Mammary amino acid utilization in dairy cows fed fat and its relationship to milk protein depression. Journal of Dairy Science 76, 762-764.

Cant, J. P. \& McBride, B. W. (1995). Mathematical analysis of the relationship between blood flow and uptake of nutrients in the mammary glands of a lactating cow. Journal of Dairy Research 62, 405-422.

Connell, A., Calder, A. G., Anderson, S. E. \& Lobley, G. E. (1997). Hepatic protein synthesis in the sheep: effect of intake as monitored by use of stable-isotope-labelled glycine, leucine and phenylalanine. British Journal of Nutrition 77, 255-271.

Evans, E. H. \& Patterson, R. J. (1985). Use of dynamic modeling seen as good way to formulate crude protein amino acid requirements for cattle diets. Feedstuffs 57, 24-27.

Fox, D. G., Sniffen, C. J., O'Connor, J. D., Russell, J. B. \& Van Soest, P. J. (1992). A net carbohydrate and protein system for evaluating cattle diets: III. Cattle requirements and diet adequacy. Journal of Animal Science 70, 3578-3596.

France, J., Bequette, B. J., Lobley, G. E., Metcalf, J. A., Wray-Cahen, D., Dhanoa, M. S., Backwell, F. R. C., Hanigan, M. D., MacRae, J. C. \& Beever, D. E. (1995). An isotope dilution model for partitioning leucine uptake by the bovine mammary gland. Journal of Theoretical Biology 172, 369-377.

France, J., Calvert, C. C., Baldwin, R. L. \& Klasing, K. C. (1988). On the application of compartmental models to radioactive tracer kinetic studies of in vivo protein turnover in animals. Journal of Theoretical Biology 133, $447-471$.

Freetly, H. C., Knapp, J. R., Calvert, C. C. \& Baldwin, R. L. (1993). Development of a mechanistic model of liver metabolism in the lactating cow. Agricultural Systems 41, 157-195.

Garlick, P. J., Millward, D. J. \& James, W. P. T. (1973). The diurnal response of muscle and liver protein synthesis in vivo in meal-fed rats. Biochemical Journal 136, 935-945.

Gerrits, W. J. J., Verstegen, M. W. A., France, J., Dijkstra, J., Tolman, G. H. \& Schrama, J. W. (1996). Modelling growth of veal calves. In Veal, Perspectives to the Year 2000, Proceedings of the International Symposium, pp. 243-253. Paris: Fédération de la Vitellerie Française.

Gill, M., France, J., Summers, M., McBride, B. W. \& Milligan, L. P. (1989). Mathematical integration of protein metabolism in growing lambs. Journal of Nutrition 119, 1269-1286.

Hanigan, M. D. \& Baldwin, R. L. (1994). A mechanistic model of mammary gland metabolism in the lactating cow. Agricultural Systems 45, 369-419.

Hanigan, M. D., France, J., Reutzel, L., Wray-Cahen, D., Beever, D. E., Lobley, G. E. \& Smith, N. E. (1996). An analysis of transorgan metabolite extraction data. FASEB Journal 10, A202.

Harris, P. M., Skene, P. A., Buchan, V., Milne, E., Calder, A. G., Anderson, S. E., Connell, A. \& Lobley, G. E. (1992). Effect of food intake on hind-limb and whole-body protein metabolism in young growing sheep: chronic studies based on arterio-venous techniques. British Journal of Nutrition 68, 389-407.

Jarrige, R. (1978). Alimentation des Bovins, Ovins et Caprins (Feeding of Cattle, Sheep and Goats). Paris: INRA. Jepson, M. M., Bates, P. C. \& Millward, D. J. (1988). The role of insulin and thyroid hormones in the regulation of muscle growth and protein turnover in response to dietary protein in the rat. British Journal of Nutrition 59, $397-415$. 
Liu, S. M., Lobley, G. E., MacLeod, N. A., Kyle, D. J., Chen, X. B. \& Ørskov, E. R. (1995). Effects of long-term protein excess or deficiency on whole-body protein turnover in sheep nourished by intragastric infusion of nutrients. British Journal of Nutrition 73, 829-839.

Lobley, G. E., Connell, A., Lomax, M. A., Brown, D. S., Milne, E., Calder, A. G. \& Farningham, D. A. H. (1995). Hepatic detoxification of ammonia in the ovine liver: possible consequences for amino acid catabolism. British Journal of Nutrition 73, 667-685.

Lobley, G. E., Connell, A., Revell, D. K., Bequette, B. J., Brown, D. S. \& Calder, A. G. (1996). Splanchnic bed transfers of amino acids in sheep blood and plasma, as monitored through use of a multiple U- ${ }^{13} \mathrm{C}-$ labelled amino acid mixture. British Journal of Nutrition 75, 217-235.

Lobley, G. E., Milne, V., Lovie, J. M., Reeds, P. J. \& Pennie, K. (1980). Whole body and tissue protein synthesis in cattle. British Journal of Nutrition 43, 491-502.

MacRae, J. C., Bruce, L. A., Brown, D. S. \& Calder, A. G. (1997a). Amino acid use by the gastrointestinal tract of sheep given lucerne forage. American Journal of Physiology (In the Press).

MacRae, J. C., Bruce, L. A., Brown, D. S., Farningham, D. A. H. \& Franklin, M. (1997b). Absorption of amino acids from the intestine and their net flux across the mesenteric and portal drained viscera of lambs. Journal of Animal Science (In the Press).

Metcalf, J. A., Beever, D. E., Sutton, J. D., Wray-Cahen, D., Evans, R. T., Humphries, D. J., Backwell, F. R. C., Bequette, B. J. \& MacRae, J. C. (1994). The effect of supplementary protein on in vivo metabolism of the mammary gland in lactating dairy cows. Joumal of Dairy Science 77, 1816-1827.

Metcalf, J. A., Wray-Cahen, D., Chettle, E. E., Sutton, J. D., Beever, D. E., Crompton, L. A., MacRae, J. C., Bequette, B. J. \& Backwell, F. R. C. (1996). The effect of dietary crude protein as protected soybean meal on mammary metabolism in the lactating dairy cow. Journal of Dairy Science 79, 603-611.

National Research Council (1984). Nutrient Requirements of Beef Cattle, 6th ed. Washington, DC: National Academy Press.

National Research Council (1985). Ruminant Nitrogen Usage. Washington, DC: National Academy Press.

National Research Council (1989). Nutrient Requirements of Dairy Cattle, 6th ed. Washington, DC: National Academy Press.

O'Connor, J. D., Sniffen, C. J., Fox, D. G. \& Chalupa, W. (1993). A net carbohydrate and protein system for evaluating cattle diets: IV. Predicting amino acid adequacy. Journal of Animal Science 71, 1298 1311 .

Oldham, J. D. (1980). Amino acid requirements for lactation in high yielding dairy cows. In Recent Advances in Animal Nutrition, pp. 53-65 [W. Haresign, editor]. London: Butterworths.

Oxender, D. L. \& Christensen, H. N. (1963). Distinct mediating systems for the transport of neutral amino acids by the Ehrlich cell. Journal of Biology and Chemistry 238, 3686-3699.

Russell, J. B., O'Connor, J. D., Fox, D. G., Van Soest, P. J. \& Sniffen, C. J. (1992). A net carbohydrate and protein system for evaluating cattle diets: I. Ruminal fermentation. Journal of Animal Science 70, 35513561 .

Simon, O. (1989). Metabolism of proteins and amino acids. In Protein Metabolism in Farm Animals, pp. 273366 [H. D. Bock, B. O. Eggum, A. G. Low, O. Simon and T. Zebrowska, editors]. Berlin: Deutscher Landwirtschaftsverlag.

Sniffen, C. J., O'Connor, J. D., Van Soest, P. J., Fox, D. G. \& Russell, J. B. (1992). A net carbohydrate and protein system for evaluating cattle diets: II. Carbohydrate and protein availability. Joumal of Animal Science 70, 35623577.

Tagari, H. \& Bergman, E. N. (1978). Intestinal disappearance and portal blood appearance of amino acids in sheep. Journal of Nutrition 108, 790-803.

Tamminga, S. (1992). Nutrition management of dairy cows as a contribution to pollution control. Journal of Dairy Science 75, 345-357.

Tamminga, S., Van Straalen, W. M., Subnel, A. P. J., Meijer, R. G. M., Steg, A., Wever, C. J. G. \& Blok, M. C. (1994). The Dutch protein evaluation system: the DVB/OEB-system. Livestock Production Science 40, $139-155$.

Tolman, G. H., Wiebenga, J. \& Beelen, G. M. (1991). The Lysine and Methionine + Cystine Requirement of Friesian Veal Calves (220-250 kg), Internal Report, I 91-3740. Wageningen: TNO Nutrition and Food Research Institute.

Van Es, A. J. H. (1978). Feed evaluation for ruminants. I. The system in use from May 1978 onwards in The Netherlands. Livestock Production Science 5, 331-345.

Vérité, R., Michalet-Doreau, B., Chapoutot, P., Peyraud, L.-L. \& Poncet, C. (1987). Revision du systeme des proteins digestibles dans l'intestin (PDI) (Reappraisal of the intestinally digestible protein system). Bulletin Technique C.R.Z.V. Theix INRA 70, 19-34.

Waghorn, G. C. \& Baldwin, R. L. (1984). Model of metabolite flux within mammary gland of the lactating cow. Journal of Dairy Science 67, 531-544.

Waterlow, J. C., Garlick, P. J. \& Millward, D. J. (1978). Protein Turnover in Mammalian Tissues and in the Whole Body. Amsterdam: Elsevier/North Holland Biomedical Press. 